International Journal of Child, Youth, and Family Studies (2014): 5(4.2) 782-807

\title{
PLAYING WITH DOLLS: (RE)STORYING GENDERED CARING PEDAGOGIES
}

\section{B. Denise Hodgins}

\begin{abstract}
Based on material discussed more fully in Chapter 4 of the author's Ph.D. dissertation (Hodgins, 2014), this article shares ordinary classroom stories of child-doll encounters that occurred during a collaborative research study that explored how children, educators, and things emerge as gendered caring subjects within early childhood practices. The historical and current dominance of dolls in early childhood practices and their links to gender and care make dolls such a significant material to think-with. Following Donna Haraway, this article works to unstick early childhood pedagogies from individualist and child-centred pedagogies, and rethink the apolitical and developmental logics that underpin "doll early childhood pedagogies". Through thinking-with dolls, new trajectories for dolls in the classroom are created. These trajectories highlight children's relations with/in the world situated within practices in, near, and far from the classroom, and the becoming of gendered caring subjects as a materialsemiotic entanglement rather than a performed or predestined linear development. Implications for caring pedagogies are considered, including the necessity for making visible the interconnectedness of gender and care, tracing how (particular) practices come to matter, and responding within the complexity of knotted webs of relationality.
\end{abstract}

Keywords: gender, care, early childhood education, pedagogical narrations, material feminism, post-qualitative research, dolls

B. Denise Hodgins, Ph.D. is a sessional instructor in the School of Child and Youth Care at the University of Victoria, P.O. Box 1700, STN CSC, Victoria, British Columbia, Canada, V8W 2Y2. E-mail: dhodgins@uvic.ca 
International Journal of Child, Youth, and Family Studies (2014): 5(4.2) 782-807

Angus is by himself at the water table playing with small buckets, pouring water over a peachy-coloured plastic girl baby doll who is sitting up in the bubbly, soapy water. He has been "bathing" this baby doll for several minutes when he shifts from pouring water on the baby to pouring some water on to the floor. He looks at me, smiles, waits. He pours some more. "I'm making a puddle right there", he announces. Angus pours some more water into his puddle. He returns to the water table and picks up the doll he had been bathing, turns and puts the doll face first "in" the puddle and slides her across the floor with his hand, smiling. He jumps over the baby, then steps on the doll, now laughing. Angus kicks the baby doll the across the floor. More laughter as Angus runs toward me. Angus quickly returns to the water table and grabs up one of the other dolls there - a dark brown boy baby doll. He brings him to the puddle, placing him down face first, and kicks him across the floor. He follows the doll, laughing, picks him up again and drops him with the first doll still lying face down on the watery floor.

In this article, I think-with dolls to consider gender and care in early childhood education. Feminist theorizing has been instrumental in efforts to challenge gender hierarchies and conceptualize care as an ethic of relationality and interdependence that is at once both private and public, and politically charged (see Gilligan, 1982/1993; Held, 2006; Noddings, 1984/2003, 2005; Ruddick, 1980/2002; Tronto, 1993). Some of the pedagogies that have taken up these feminist perspectives in their calls for an ethic of care in the classroom continue to trouble the care and gender relationship (Cameron, Moss, \& Owen, 1999; Dahlberg \& Moss, 2005; Moss \& Petrie, 2002; Noddings, 2005). While these pedagogies importantly challenge simplified, uncontextualized notions of both gender and care, they do not necessarily attend to the complexity of children's increasingly global, mobile, technological worlds (see Blaise \& Taylor, 2012; Taylor, 2013; Taylor \& Blaise, 2014; Taylor, Blaise, \& Guigini, 2012; Taylor \& Guigini, 2012) as they are stuck in individualistic human-centred accounts and strategies.

To unstick early childhood pedagogies from these individualist and child-centred pedagogies, I play with the dolls that Angus plays with to rethink the apolitical and developmental logics that underpin "doll early childhood pedagogies". It is both their historical and current dominance in early childhood practices and their materialsemiotic i links to gender and care that make dolls such a significant material to think-with. I argue that taking dolls seriously might teach us something about our pedagogies, our taken-forgranted knowledges, and ultimately about our becoming of caring gendered subjects. It might lead us, as Haraway (1994) says, to become worldly or to make our pedagogical choices and practices of the world. Throughout the article, I follow histories and trajectories of the dolls that live in Angus' classroom to ask: world?

1. How might dolls deepen our understandings of children's relations with the 
International Journal of Child, Youth, and Family Studies (2014): 5(4.2) 782-807

2. How might emerging ideas in feminist science studies assist early childhood education to respond to interconnected ideas of gender and care that emerge through thinking-with dolls?

I begin this article with a brief overview of my theoretical framework and a description of the research study that I draw on throughout. I consider the abundance of dolls and their expected role within early childhood settings, as well as some of the gendered critiques that have emerged. I then further explore the complexity of dolls through their plasticity and attend to some difficulties such as: consumerism, production, health issues related to plastics, pollution, and inequitable working conditions. I conclude the article with thoughts about practice as a complicated, socio-historical, political, and ethical endeavour where actions and decisions are made every day that must be about children's well-being and beyond. Choosing with care.

\section{Theoretical Framework and Mode of Inquiry}

This article is inspired by theoretical positions that attend to the material and discursive as co-constituted, what some refer to as new materialisms (e.g., Coole \& Frost, 2010; van der Tuin, 2008) or material feminism (e.g., Alaimo \& Hekman, 2008; Taylor \& Ivinson, 2013). While these are contested terms ${ }^{\text {ii }}$, with ideas embedded in a rich theoretical genealogy beyond the scope of this paper, there are particular resonances that permeate through it. Of significance is the recognition that both matter and discourse matter (Barad, 2007); neither is privileged at the expense of the other (Hekman, 2010). Mattering is understood as always-becoming, a co-constitutive emergence (Taylor \& Invinson, 2013). Importantly, within this conceptualization, matter itself is not understood from a representational or social constructivist perspective, where matter is "out there" to be known or to construct knowledge about, but rather as agentic (see Barad, 2007; Bennett, 2010). Paying attention to what Bennett refers to as "the force of things", produces a flattening of human and non-human hierarchies and challenges the anthropocentricism of much Anglo-Western theorizing and researching methodologies. Material feminist approaches engage with the insights of linguistic constructionism (Hekman, 2010) and the "very rich history of feminist engagements with materialism" (Barad, as cited in Juelskær \& Schwennesen, 2012, p. 13). "Knowing and being are not isolable; they are mutually implicated” (Barad, 2007, p. 185).

I ask the questions noted above and create new trajectories for dolls in the classroom as I draw on the work of Donna Haraway, and other feminist scholars who have also drawn on her work, to engage with matter and discourse (Barad, 2007; Puig de la Bellacasa, 2009, 2010, 2012). Indeed, thinking-with dolls is a Haraway-inspired articulation and effort. "Haraway's thinking-with creates new patterns out of previous multiplicities, intervening by adding layers of meaning rather than questioning or conforming to ready-made categories” (Puig de la Bellacasa, 2012, p. 200). My utilization of dolls as a figure to think-with is indebted to Haraway's (1997) use of figurations as "performative images ... condensed maps of contestable worlds ... to make explicit and inescapable the tropic quality of all material-semiotic processes” (p. 11). Through such figures as cyborgs (Haraway, 1991), OncoMouse (1997), and 
companion species (2008), Haraway problematizes dualisms and challenges "the categorical purity of nature and society, nonhuman and human” (Haraway, 1994, p. 66). Haraway's serious play with figures foregrounds relationality. Humans, nonhumans, language, technology, past, presents and futures do not exist in isolation but are entanglements, always in-the-making through their intra-action iii (see Barad, 2007, 2011) within naturecultures ${ }^{\text {iv }}$. As Haraway (1994) aptly suggests, "human and nonhuman, all entities take shape in encounters, in practices; and the actors and partners in encounters are not all human, to say the least” (p. 62).

Working within a post-qualitative research perspective (Davies et al., 2013; Jackson, 2013; Lather, 2013; Lather \& St. Pierre, 2013; MacLure, 2013; St. Pierre, 2011, 2013), I am not interested in gender and care in terms of an individual autonomous subject but rather in terms of entanglements and the materialization of naturecultures. The inseparability that figures throughout Haraway's work is of profound importance for rethinking how gender and care are always already "in the making”, both "built into practice” (Haraway, 1994, p. 67). With Haraway (1988), dolls, children, gender, and care cannot be conceptualized as bounded entities or as causally related. This perspective helps to unstick constructions of gender and care from social/biological binary explanations, as well as loosen the ties that bind gender constructions as explanations for care and vice versa. Considering "what gets to count as nature and who gets to inhabit natural categories” (Haraway \& Goodeve, 2000, p. 50) is of utmost importance for pedagogies of care working to attend to the complexity of our increasingly technological, mobile, and global worlds. From the perspective of materialsemiotic relationality, gender and care can be conceptualized as performatively emerging through the iterative intraactivity of "bodybrains and the material and temporal environment" (Hultman, 2009, p. 25). This isn't to say that human bodies are unimportant in (re)constructions of gender and care but rather, as Puig de la Bellacasa (2010) suggests, "living in naturecultures requires a perspective on the personal-collective that, without forgetting human individual bodies, doesn't start from these bodies but from awareness of their interdependency” (p. 167). It is from this perspective that I consider dolls and children together

in situated histories, situated naturecultures, in which all the actors become who they are in the dance of relating, not from scratch, not ex nihilo, but full of the patterns of their sometimes-joined, sometimes-separate heritages both before and lateral to this encounter. All the dancers are redone through the patterns they enact. (Haraway, 2008, p. 25)

In line with my Haraway-inspired theoretical approach and with post-qualitative research perspectives, I follow a diffractive methodology (Barad, 2007; Haraway, 1994, 1997; Haraway \& Goodeve, 2000) in this article through the telling of stories. To think with diffraction ${ }^{\mathrm{v}}$ is to attend to the effects of differences and relationalities, "to get at how worlds are made and unmade, in order to participate in the processes, in order to foster some forms of life and not others” (Haraway, 1994, p. 65). I pay attention to everyday small encounters, events, and relations among children and dolls in the classroom and trace the geohistorical trajectories of these events (children and dolls) to 
find out how they came to be there and investigate their interrelations, interdependencies, and co-shapings. I also link these encounters to the developmental and gendered logics that have shaped them. Through my storytelling and tracings, "diffractively reading insights through one another for patterns of constructive and deconstructive interference" (Barad, as cited in Juelskær \& Schwennesen, 2012, p. 12), I generate new insights about children and dolls, caring and gendered practices, and the kinds of worlds that children inherit and inhabit. As Haraway (2012) suggests, "There is no innocence in these kin stories, and the accountabilities are extensive and permanently unfinished” (p. 311). I do not tell these stories as truths of practice, but rather as partial, incomplete knotted stories, with the belief that through sharing stories of complexities in practices, we can generate new knowledges and work toward actualizing new material realities.

The ordinary and mundane classroom stories I tell, such as the one in the opening narration, is one of several child-doll encounters that occurred during a collaborative research study that engaged with pedagogical narrations to explore how children, educators, and things emerge as gendered caring subjects within early childhood practices (Hodgins, 2014). Pedagogical narrations is a process of observation, documentation, interpretation, dialogue, and (re)interpretation, wherein a group (e.g., researchers, educators, and children) work collectively to experiment with interpretations and questions (for an overview of pedagogical narrations as a methodology, see Hodgins, 2012; Hodgins, Kummen, Rose, \& Thompson, 2013). This study took place in a small urban city in Western Canada at a childcare program with 10 children aged 18 months to 3 years, and with four full-time early childhood educators. All four of these educators participated as co-researchers. Over the course of a month, the educators and I documented moments of practice through photographs, videos, and written observations. We shared our initial and ongoing (re)interpretations with each other and the children in several ways (e.g., photographs printed and displayed in the classroom, videos and photographs projected on a classroom wall, informal conversations on the floor, e-mail and written notes, scheduled recorded meetings) through that initial month within the classroom and two months that followed.

The educators and I looked at the data generated in/with/through pedagogical narrations not as representative of "what was going” but rather as traces of events. The classroom stories I share here through narratives emerged from those moments and dialogues. They are interspersed among the other doll stories I tell to be diffractively read through each other, with the aim to interfere with the expected, add layers of meaning, challenge assumptions, and raise questions of implication and response-ability ${ }^{\mathrm{vi}}$ (Haraway, 2012). I begin by briefly touching on the "sometimes-joined" heritages (of dolls, children, ECCE, research) and consider the taken-for-grantedness of dolls in Early Childhood Care and Education (ECCE). Then, I address some of the ways that dolls, gender, and care have been, and continue to be, entangled. The section that follows attends to the plasticity of the dolls to argue that this material is as situated, political, and problematic/contradictory as the dolls themselves. The article concludes with more questions about the implications this storying may hold for pedagogies and the emergence of gendered caring subjects. 
International Journal of Child, Youth, and Family Studies (2014): 5(4.2) 782-807

\section{Dolls, Dolls, Dolls: Why So Many Dolls?}

The act of playing with a doll is like no other act. Nor is it like any other type of play that happens in the early years of our little ones. Giving a child a doll is like giving a child a tool from which he can express himself and give himself full range of the many facets of adulthood that he can mimic and weave into his learning experiences. (Disch, 2012, para. 1)

In this section I consider the dolls in our research study and their past-present entanglement with developmental psychology, education, marketing, and the governing of practices related to early childhood. Dolls have been part of most cultures throughout history: as sacred objects used for ceremony or ritual, tools for information sharing, and as toys for both adults and children (Jaffé, 2006). Dolls remain a popular toy choice for children in the home and in childhood settings, in spite of the enormous selection of toys available to children. Dolls designed, produced, marketed, bought, and played with come in numerous shapes, sizes, colours, qualities, and personalities, and a browse through any local or online toy store will highlight the multitude of doll possibilities that exist today. A child interacting with baby dolls among bubbles in a water table, like Angus and the dolls in the opening narration, is likely a familiar scene for those who have spent time in a childcare centre in Western contexts. In curriculum guidelines for educators who work with young children, baby dolls are listed and described in a taken-for-granted way as a standard material to provide children in what are referred to as developmentally appropriate ECCE practices (e.g., Beaty, 2012; Bundy, 1989; Copple \& Bredekamp, 2009; Government of British Columbia, 2009, n.d.a, n.d.b.; Government of Manitoba, n.d.). Within these guides, dolls and doll paraphernalia are typically included as part of a dramatic play area and their play (education) value is varyingly categorized as supporting children's socio-emotional, physical, and cognitive development.

Parents are also taught about the variety of ways that miniature figures such as dolls purportedly support children's developmental well-being through information guides for parents produced and distributed by government (e.g., Government of British Columbia, 2007) and the growing number of parenting blogs (e.g., Disch, 2012; Mama OT, 2012) and websites (e.g., BabyCenter Canada, 2013; The Bump, n.d.). So the developmental value of dolls in a water table need not be reserved for toddlers in an ECCE setting like Angus; parents can provide opportunities for pretend baby doll bathing that will support the development of fine motor skills, self-care, and the knowledge of body part names (BabyCenter Canada, 2013). Parents and educators can also be reminded of the developmental value of doll play by retailers and manufacturers who overtly promote the "importance of doll play" (Corolle, 2012, para. 2) and assure customers that they have dolls to support each "age and stage" of children's development (see Corolle, 2012; Zapf Creation, 2009). While manufacturers, parenting blogs, and parent and educator guidebooks do not necessarily ignore that dolls may be a toy that is enjoyable to play with, the discourse of play as a function in developmental (e.g., psychological, sociological, physical) processes is the overriding message (for an overview of the relationship between developmentalism and the rhetoric of play, see Sutton-Smith, 1997). 
International Journal of Child, Youth, and Family Studies (2014): 5(4.2) 782-807

The inheritance of this need for, or legitimization of having, dolls in an ECCE setting comes from progressive education ideals and the child study movement at the turn of the 20th century. Dewey was a leader in the progressive education movement and his early work at the University of Chicago Laboratory Schools was instrumental in shaping ideas about education and children. One of the ideals of progressivism was that curriculum should be derived from children's own experiences and interests (e.g., Dewey, 1897, 1912, 1915), which impacted the didactic materials that were made available in schools. By the 1920s and 1930s, the curriculum in liberal kindergartens (those most aligned with progressive movement ideals) included dolls as a material for what was termed "household arts" - today often referred to as the home corner, house area, or daily living area (Prochner, 2011). The closest Canadian equivalent to Dewey's lab schools and other child study schools in the United States in the 1920s and 1930s was the Child Study Institute at the University of Toronto (Rubin, 1975). With William Blatz as director of the institute from 1926 to 1964 (Rubin, 1975; Winestock, 2010), the research conducted through its nursery school and parent education program (StrongBoag, 1982) was extremely influential in shaping views and practices related to childcare in Canada (Varga, 1997). Among many publications, Blatz with his colleagues Dorothy Millichamp and Margaret Fletcher produced a treatise on nursery education theory and practice that outlined the developmental value of dolls as a tool for imaginative play suitable for both younger (2- to 3.5-year-olds) and older (3.5- to 5-year-olds) children (Blatz, Millichamp, \& Fletcher, 1935). According to these authors, linguistic, social, physical, and cognitive development are all (potentially) supported through doll play, and as a child's maturation brings increased capacities, the play and the play objects can (and should) become more sophisticated. Arguably, this psychologizing begins with American psychologists G. Stanley Hall and A. Caswell Ellis when they conduct a rather large study about doll play and theorize its significance for "both psychology and pedagogy" (Ellis \& Hall, 1896, p. 129). This reflects the child study movement's reach beyond psychology to the scientization of pedagogy and parenting, in particular mothering (see Pacini-Ketchabaw, 2005; Strong-Boag, 1982; Varga, 1997).

One example of dictating scientific motherhood is a 1934 resource booklet produced by The Canadian Welfare Council aimed at helping "Canadian mothers at risk" with appropriate materials and play spaces for preschool-aged children (Mitchell, 1934/1942). According to the resource, "toys are essential” at this stage in a healthy child's development. This government resource also highlights the entangled relationship between psychology (e.g., the developmental value of particular forms of play), progressive education ideas (e.g., child-sized materials that mimic the adult world), and marketing (e.g., the overt promotion of brands of toys). Thrift (2003) notes John Locke is usually credited with introducing the notion that (particular) toys (should) have developmental value but the child study movement of the early 20th century greatly impacted the spreading of this idea. Designing, marketing, and selling toys for didactic purposes have certainly added to the (Western) abundance of toys in general through the 20th and now the 21st century (Thrift, 2003). The Milton Bradley Company (MBC) is one example of this, targeting both the home and the classroom consumer. Bradley himself was an early kindergarten advocate and his company published many books 
International Journal of Child, Youth, and Family Studies (2014): 5(4.2) 782-807

about kindergarten, in addition to producing many of the "necessary" materials for the kindergarten classroom (Prochner, 2011). Included in offerings of the 1927 MBC catalogue were "Bradley's Kindergarten Dolls" which the company assured met the standards of the "International Kindergarten Union Standardization Committee”. Doll play in itself was approved for kindergarten and primary grades by leading educators (as cited in Prochner, 2011, p. 371).

A baby doll lies in an oval handled basket. The basket is just the right size for the doll. The handle nicely suits the size of the hand that lifts and carries it throughout the centre. The basket baby doll carrier sits on the floor of the classroom, waiting for block building to be done. Eventually, fingers grab the handle and then it's nestled into the crook of an arm. Perfect to carry and walk: to wander through different areas and rooms of the centre to the back corner where a set-up of paper and bingo dabbers awaits. Basket baby doll carrier now sits on the table, on top of the already painted paper. The red dabber is picked up and used to dot, dot, dot, dot the baby doll lying in the basket carrier.

\section{Doll Troubles}

Dolls are overtly connected to nurturance and often considered a gender-typed toy to study such constructs as gender differences, same-sex friend/peer group preferences, gender stereotyping, and gender role behaviour (e.g., Banerjee \& Lintern, 2000; Banse, Gawronski, Rebetez, Gutt, \& Morton, 2010; Blackmore, 2003; Cherney, 2003; Eisenberg, Murray, \& Hite, 1982; Golombok, Rust, Zervoulis, Croudace, Goulding, \& Hines, 2008; Kuhn, Nash, \& Brucken, 1978; Martin, Eisenbud, \& Rose, 1995; Miller, 1987; Taylor, 1996; Theimer, Killen, \& Stangor; 2001). From a developmental perspective, through engaging with dolls, children are imitating what they see or experience from the adult world; in other words, practicing for their adult life to come (Blatz et al., 1935; Bundy, 1989; Ellis \& Hall, 1896). This has helped to foster the enduring belief that by playing with (baby) dolls, children are practicing the skill/duty/pleasure of physically and emotionally caring for others. The aim of this section is to further highlight the complex web of dolls and children by sharing stories that highlight a few knots related to gender and care.

Basten (2009) highlights, "young girls playing with dolls [as] probably one of the most visibly familiar images of early child interaction with childbearing and nurturing" (p. 2). This "familiar image" is plastered throughout current doll advertising (e.g., Corolle, 2012; Toys R Us Canada, n.d.; Zapf Creation, 2009) where photos of smiling girls playing with dolls in a sea of pink, that quintessential marker of girlhood, advertise dolls "for the littlest mommies" (Corolle, 2012). While boys do play with dolls (almost every boy in the centre played with a doll at some point during the research) and have for quite some time (see Blatz et al., 1935; Ellis \& Hall, 1896), they are rarely marketed to as the consumer of dolls. In Formanek-Brunell's (1993) overview of doll production in the U.S. from 1830 to 1930, she assesses that by the 1920s, nearly all American doll manufacturers were marketing their dolls "to emphasize domesticity, maternity, and femininity” (p. 181). 
International Journal of Child, Youth, and Family Studies (2014): 5(4.2) 782-807

A review of several Eaton's catalogues ${ }^{\text {vii }}$ (T. Eaton Co. Limited, 1897, 1909, 1920, 1934) illuminates a similar marketing trend, as well as the increase in infant doll production, in the early 20th century in Canada. The Eaton's 1897 Christmas Catalogue includes a small section for toys that advertised a few "kid body dolls" (T. Eaton Co. Limited, 1897, p. 18) but by the 1934-35 Fall and Winter catalogue, dolls are no longer advertised as toys for "the little folks" but are now promoted under the page heading: "Every little mother will fall in love" (T. Eaton Co. Limited, 1934, p. 258). Rather than selling the technical details of the dolls as earlier catalogues emphasized, the marketing of maternity becomes overt, and rather similar to what we see in marketing today. This connection between dolls, girls, and nurturing has certainly received comment and

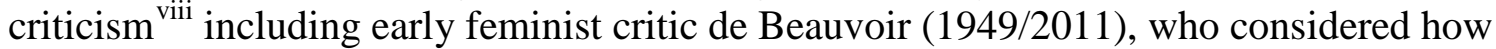
dolls were implicated in the indoctrination of girls "to become caring, maternal, and passive” (Wagner-Ott, 2002, p. 251).

With de Beauvoir's (1949/2011) infamous assertion "One is not born a woman, but, rather, becomes one" (p. 283), previously accepted assumptions of the "naturalness" of gender hierarchy/relations could now be theorized as "a social condition constituted through relations of power, thus open to critique and the possibility of change” (Dietz, 2003, p. 401). This possibility of change does not get missed within discourses and practices related to dolls. One way these ideas get taken up is to include boys in the dolls and nurturing discourse and practices, exemplified in Charlotte Zolotow's (1972/2002) children's picture book William's Doll, an adaptation of which was included in the early 1970s liberal feminist collection of iconic stories, songs, and poems known as Free to Be You and Me (see Hart, Pogrebin, Rodger, \& Thomas, 2008). The grandmother's explanation is clear that boys need dolls so they can "practice being a father" (Zolotow, 1972/2002, p. 286) presumably just the way girls have had the opportunity to practice being a mother. This challenges the exclusion of boys from the nurturing/caring discourse and practices related to dolls, but perpetuates the notion that playing with dolls is preparatory for a future parenting self. When efforts to change gendered behaviour (such as boys should play with dolls to develop their nurturing capabilities) "fail”, biological determinism is often called upon to explain behaviour (MacNaughton, 2000). Biological determinism is generally rooted in discourses of essential, universal difference: developmental difference, biological difference, emotional difference, functional difference (Eidevald, 2009). As Sommers’ (2012) online article title suggests, “you can give a boy a doll, but you can’t make him play with it”.

The past-presents (presence) of dolls teaching/playing in ECCE is not outside gendered discourses and practices of care. Woven into the fabric of developmental value discourses with respect to dolls are gendered questions (assumptions) of who will (should) care for dolls that parallel questions of who will (should) care for children. Dominant biological and social theories of gender do little to disrupt the male/female binary associated with care (see Cameron et al., 1999; Johnson, 2011). To unstick care from this dichotomous gender quarrel, a more expansive view of gender and care that can account for the complexity of material-semiotic becomings is required. 
International Journal of Child, Youth, and Family Studies (2014): 5(4.2) 782-807

A wooden dollhouse sits on the floor of the classroom. Three children walk around the dollhouse driving die-cast cars on the dollhouse roof. Baby cars they have come to be called. A "baby car" pokes in through the dollhouse window only to re-emerge quickly, back to roll over the roof. Walking. Rolling. Some talking. Mostly just baby cars on the dollhouse roof. A plastic baby doll wrapped in a blanket is tucked under one of the children's arms as she drives her baby car on the roof.

\section{A Knotty Tale of Plasticity}

This story takes as its starting point the plastic material of the dolls with whom the children of this study engage. While it is a material that largely influences the play possibilities (e.g., water table bathing dolls) in ECCE, it is also one embroiled in controversy. Considering (critiquing) dolls in ECCE typically rests within developmental and (dominant) gender logics: Exceptions include Taylor and Richardson's (2005) poststructural and queer theory analysis and Gallacher's (2006) Deleuzian analysis of home/doll corner. In this section, my aim is to consider the plasticity of the dolls, and in so doing add several more sticky knots to the complicated, sometimes contentious, web of dolls, children, gender, and care. As Puig de la Bellacasa (2009) suggests "these worlds of collective feeling, relational processes that are far from being always caressing, have something specific and situated to teach us” (p. 310).

Depending on the resources available and the cultural tradition of the people involved, dolls have been made from: wood; paper; food, such as cornhusks and apples; terracotta and clay; porcelain china; rags and other kinds of cloth; rubber; and various kinds of plastic (Fraser, 1966; Jaffé, 2006). With the development of polymers (i.e., polyurethane in the 1930s, followed by polystyrene, and by the 1950s polypropylene) which could support various types of molding and be mass produced cheaply, hard plastics overtook doll production by the mid-20th century (Jaffé, 2006). Plastic production is implicated in the variety of doll shapes and sizes and the abundance of dolls available then and today in ECCE classrooms and homes. Plastic also helped to facilitate different play possibilities as the dolls were now lighter and easier to carry or move around; they could be washed and left outside in the rain without (much) worry; they did not break (as easily) and therefore could be played with under less supervision than porcelain dolls (Formanek-Brunell, 1993). Originally marketed as better for children's play - plastic is hygienic, safe, durable, and cheap - today, plastic dolls are embedded in multiple controversies related to physical and environmental health.

In terms of physical health, chemicals found in plastics, such as bisphenol A (BPA) which is used as a binding agent in polycarbonates, are increasingly being associated with delayed puberty, growth retardation, cancer, diabetes, obesity, as well as reproductive and neurological problems or diseases (see Grossman, 2009; Knoblauch, 2009; Kovacs, n.d.; Schmidt, 2011; White, 2009). Phthalates, a chemical compound used to soften plastic in the production process, is also of concern. Like BPA, phthalates are not chemically bound to the plastic and therefore in different ways leach into the environment, including migrating into the body through saliva (Schmidt, 2011). In terms 
of environmental health, producing plastic consumes a large amount of non-renewable resources, such as petroleum and coal, both for the actual product and the process of production (Knoblauch, 2009; Kovacs, n.d; White, 2009). Not only are non-renewable resources used to make plastic products but major air, water, and soil pollution is also created through their production and disposal, which is also impossible to disentangle from human and non-human health (Allsopp, Walters, Santillo, \& Johnston, 2006; Grossman, 2009). Much of the general concern related to plastic production gets directed toward China, as the world's largest producer of plastics (Pop, 2011). Dolls are among the many plastic products whose manufacturing has migrated to China over the last 20 years in the pursuit of reduced production costs (Jaffé, 2006; Van Patten, n.d.).

Among the health and environmental problems that have been raised are strong concerns about the conditions related to toy production in China, which is estimated to be $80 \%$ of the world's toy production (Bjurling, 2005, 2009; Jaffé, 2006). Most production occurs within the Guangdong Province and severe working conditions have been reported that often violate Chinese legislation, international conventions, as well as companies' own codes of conduct: extremely long working hours, little to no days off from work (particularly in peak season), lack of safety and health education, and low-wages (Bjurling, 2005; Ekelund \& Bjurling, 2004). Added to this is concern for the health of the 105 million permanent residents (as of 2011) of the Guangdong Province due to severe soil, air, and water pollution (Chow, 2012; Fung, 2013; Gong, 2013; McGeary, 2013). It is difficult to not see a dichotomy here between the plastic baby dolls played with in a childcare centre on the west coast of what is regularly described as "beautiful British Columbia” and the highly polluted province of Guangdong where these dolls in all probability came from.

Pressure from public reporting, such as Ekelund and Bjurling (2004), and other safety issues, such as a massive recall of toys containing lead in 2007 which saw the largest toy manufacturer Mattel recall 21 million toys made in China (Bjurling, 2009) have led to many efforts to improve working conditions (Bjurling, 2009, 2011; Toloken, 2012). They have also led to growing concern about consumers supporting production from China as portrayed in mainstream media (e.g., Rosevelt, 2006; Thottam, 2007), ECE newsletters (e.g., Stoecklin, 2008), and parenting or mommy blogs (e.g., Bernadette1, 2013; Cool Mom Picks, 2007; Journey to Crunchville, 2007; Mommy Footprint, 2012; Morris, 2012; Sarnoff, 2003). Bernadette1 (2013) asks her readers where a doll "not made in China" can be acquired. Journey to Crunchville (2007) notes that a recall of plastic baby dolls accelerated her move to rid the house of her daughter's "gazillion plastic babies” (para. 1). Sarnoff (2003) describes the first night that followed her daughter being given a plastic baby doll by well-intentioned but ill-informed grandparents: "All night I smelled Baby Ava as she emitted a powdery chemical scent so powerful it made me gag. Baby Ava was off-gassing” (para. 4-5). Suffice it to say that Baby Ava was gone the next day. Sarnoff (2003) clearly indicates there are simply two doll purchasing choices: "potentially lethal lead poisoning or organic cotton options" (para. 3). 
International Journal of Child, Youth, and Family Studies (2014): 5(4.2) 782-807

With cotton and wool handmade dolls such as Waldorf dolls (Bernadette1, 2013; Disch, 2012) and Bamboletta dolls (Cool Mom Picks, 2007; Mommy Footprint, 2012) costing upwards of $\$ 700$ each (Elton, 2013), deciding which doll to buy becomes an issue of access as well as sustainability. Furthermore, what happens to all the plastic dolls in our caring efforts to "go green” or "choose wisely”? In a growing push to shift from plastic materials to natural ones in early childhood environments (e.g., cotton, wool or wood dolls; wood blocks; wood play structures and furniture) (e.g., Smart baby, smart kid, 2013) where does all the plastic go when we make this adjustment? Where did baby Ava go in Sarnoff's (2003) efforts to protect her infant daughter from “off-gassing”? To another child whose parent or educator is less informed or enlightened? To a recycling depot or a landfill? Are we as consumers prepared to see and take action around our culpability - what we purchase, from where we purchase, and how we dispose - in this knotty tale of plasticity? What are our "obligations of care” (Haraway, 2008, p. 70)?

One of the challenges associated with adhering to international standards and ethical calls for "good practice" is an unwillingness to share (i.e., among manufacturers, retailers, and consumers) the accompanying extra costs (e.g., increasing wages, assuring safe working conditions and materials) that ultimately result in increased prices for goods manufactured, like dolls (Bjurling, 2009; Toloken, 2012; Van Patten, n.d.). As Puig de la Bellacasa (2010) suggests, “the obligation 'to care' is more than an affective state, it has material consequences” (p. 165).

Ruby holds one of the baby dolls in her hands, sitting with her and trying to add another dress to the dolls' layers. She looks at Terry, the educator in the room who is near to Ruby and asks for help getting another dress on to the doll. Terry helps wiggle the dress onto the doll. 'There you go'. She smiles at Ruby and hands her back the doll. Ruby continues to play with the baby doll but then asks Terry for help to wrap the doll into the blanket she has on her lap. 'Oh, does your baby need a blanket'? Terry helps Ruby by carefully wrapping the doll with the baby blanket. 'There's your baby'. She hands the baby doll back to Ruby, who scoops the baby into her arms. She places the baby doll down on the carpeted floor and then lies down beside her. 'Are you having a nap with your baby'? Ruby smiles, not at Terry or I, but at her baby.

\section{Following Trajectories with Dolls}

In this article, I have told several stories of child-doll encounters from the classroom that each, in varying ways, could be interpreted as moments of pleasure, enjoyment and contentment. While there are many ways to interpret children's doll play, like that of Angus, Ruby, "baby cars", what I am most interested in is that these seemingly pleasurable, multiple ways of being with dolls exist alongside and within the partial, incomplete tale of plasticity I have just told. In our obligations to care, whom do we care about in these practices? The children's enjoyment with the plastic doll that can be soaked and painted and kicked and cuddled with relative ease? The working conditions under which this doll was likely produced? The environmental hazards of this doll's production, use, and disposal? How do we weigh the care/concern of one over the 
other? And is one over the other the only option we have? Puig de la Bellacasa (2012) suggests that, "where there is relation there has to be care, but our cares also perform disconnection. We cannot possibly care for everything, not everything can count in a world, not everything is relevant in a world” (p. 204). What might caring pedagogies look like, then, in this world of dis/connections?

Drawing on emerging ideas in feminist science studies, caring pedagogies might respond to interconnected ideas of gender and care by thinking with care which, as Puig de la Bellacasa (2012) proposes, invites us to consider how "our cuts foster relationship" (p. 204). This is about our implication and response-ability but it is not about categorical blame or romanticized visions of seamless relations. We will not be able to care for all, all of the time, but we can pay attention to the mattering of our practices. Barad (as cited in Juelskær \& Schwennesen, 2012) explains it this way: "performing the labor of tracing the entanglements, of making connections visible, you're making our obligations and debts visible, as part of what it might mean to reconfigure relations of spacetimemattering” (p. 20). In other words, Barad's assertion, like Haraway’s (1994) call for "getting at how worlds are made and unmade" (p. 65), stresses the importance of making visible how (certain) practices come to matter, not simply as a form of critique but "in order to participate in the processes, in order to foster some forms of life and not others" (p. 65, italics added). Through mapping our partial connections with the question "to what and whom is a response required?" (Gane \& Haraway, 2006, p. 145), we can do the work to reconfigure more liveable common worlds. This is not to suggest that if we work hard enough we will be able to disentangle the knots and smooth out the complexity (of, for example, children, dolls, plastic, gender, care). Caring pedagogies require that we stay with the complexities, share in the suffering.

Maybe sharing suffering is about growing up to do the kind of time-consuming, expensive, hard work, as well as play, of staying with all the complexities for all of the actors, even knowing that will never be fully possible, fully calculable. Staying with the complexities does not mean not acting, not doing research, not engaging in some, indeed many unequal instrumental relationships; it does mean learning to live and think in practical opening to shared pain and morality and learning what that living and thinking teach. (Haraway, 2008, p. 83)

I have argued that taking dolls seriously might teach us something about our pedagogies, our taken-for-granted knowledges, and ultimately about our becoming of caring gendered subjects. The many doll stories I have shared suggest several things, including that dolls are more than merely developmental tools for future selves. By tracing some of dolls past-presents (presence) in ECCE, developmental psychology, production and marketing, the becoming of caring gendered subjects is made visible as a materialsemiotic entanglement. Through thinking-with dolls, children's relations with/in the world as situated within materialsemiotic practices in, near, and far from the classroom become evident. We - dolls, children, educators, researchers - "become who we are in the dance of relating" (Haraway, 2008, p. 25); becomings that are not bounded entities, preformed, predestined, or transcendent of the ethics and politics of being of the world. 
International Journal of Child, Youth, and Family Studies (2014): 5(4.2) 782-807

\section{References}

Ahmed, S. (2008). Open forum imaginary prohibitions. Some preliminary remarks on the founding gestures of the "new materialism”. European Journal of Women's Studies, 15(1), 23-39. doi: 10.1177/1350506807084854

Alaimo, S., \& Hekman, S. (Eds.). (2008). Material feminisms. Bloomington, IN: Indiana University Press.

Allsopp, M., Walters, A., Santillo, D., \& Johnston, P. (2006). Plastic debris in the world's oceans. Amsterdam: Greenpeace International. Retrieved from http://www.greenpeace.org/international/en/publications/reports/plastic_ocean_re port/

BabyCenter (Canada). (2013). Clean, clean baby. San Francisco: Author. Retrieved from http://www.babycenter.ca/a1041108/clean-clean-baby

Banerjee, R., \& Lintern, V. (2000). Boys will be boys: The effect of social evaluation concerns on gender-typing. Social Development, 9(3), 397-408. http://dx.doi.org/10.1111/1467-9507.00133

Banse, R., Gawronski, B., Rebetez, C., Gutt, H., \& Morton, J. B. (2010). The development of spontaneous gender stereotyping in childhood: Relations to stereotype knowledge and stereotype flexibility. Developmental Science 13(2), 298-306. http://dx.doi.org/10.1111/j.1467-7687.2009.00880.x

Barad, K. (2007). Meeting the universe halfway: Quantum physics and the entanglement of matter and meaning. Durham, NC: Duke University Press.

Barad, K. (2011). Nature's queer performativity. Qui Parle: Critical Humanities and Social Sciences, 19(2), 121-158. doi: 10.1353/qui.2011.0002

Basten, S. (2009). The future of human reproduction. Working paper \#9: Dolls, toys and formative attitudes towards children and childbearing. Oxford: St. John's College. Vienna: Institute of Demography.

Beaty, J. J. (2012). Preschool appropriate practices (4th ed.). Boston: Cengage Learning

Bennett, J. (2010). Vibrant matter: A political ecology of things. Durham, NC: Duke University Press.

Bernadette1. (2013). Dolls not made in China. Retrieved from http://www.squidoo.com/dollsnotmadeinchina

Blackmore, J. E. (2003). Children's beliefs about violating gender norms: Boys shouldn't look like girls, and girls shouldn’t act like boys. Sex Roles, 48(9/10), 411-419. 
International Journal of Child, Youth, and Family Studies (2014): 5(4.2) 782-807

Blaise, M., \& Taylor, A. (2012, January). Using queer theory to rethink gender equity in early childhood education. Young Children, 88-97.

Blatz, W. E., Millichamp, D., \& Fletcher, M. (1935). Nursery education, theory and practice. New York: William Morrow and Company.

Bundy, B. F. (1989). Dolls in the early childhood classroom. Daycare and Early Education, 65(Summer), 6-8. Retrieved from http://link.springer.com/article/10.1007\%2FBF01619370\#page-1

Bjurling, K. (2005). “Easy to manage”: A report on Chinese toy workers and the responsibility of the companies. Stockholm: Swedwatch.

Bjurling, K. (2009). Reviewing Santa’s workshop. Stockholm: Swedwatch.

Bjurling, K. (2011). The toy industry acts on critique: Improvements made but factory conditions still a problem. Stockholm: Swedwatch.

Cameron, C., Moss, P., \& Owen, C. (1999). Men in the nursery: Gender and caring work. London: Paul Chapman Publishing. http://dx.doi.org/10.4135/9781446219348

Cherney, I. D. (2003). The effects of stereotyped toys and gender on play assessment in children aged 18-24 months. Educational Psychology, 23(1), 95-106. http://dx.doi.org/10.1080/01443410303222

Chow, C. (2012, August 11). Guangdong pollution at its worst in decades. Retrieved from http://www.scmp.com/article/583306/guangdong-pollution-its-worstdecades

Cool mom picks. (2007, September 18). Dolls made in not China. Retrieved from http://www.coolmompicks.com/2007/09/dolls_made_in_not_china.php

Coole, D., \& Frost, S. (Eds.). (2010). New materialisms. Durham, NC: Duke University Press.

Copple, C., \& Bredekamp, S. (Eds.). (2009). Developmentally appropriate practice in early childhood programs (3rd ed.). Washington, DC: National Association for the Education of Young Children

Corolle. (2012). Dolls for every age. Retrieved from http://us.corolle.com/p-dolls-forevery-age.html

Crozier, J. (2014, January 2). Children at play: The war on pink. Independent Australia. Retrieved from http://www.independentaustralia.net/life/lifedisplay/children-at-play-the-war-on- pink,6031

Dahlberg, G., \& Moss, P. (2005). Ethics and politics in early childhood education. London: RoutledgeFalmer. 
International Journal of Child, Youth, and Family Studies (2014): 5(4.2) 782-807

Davies, B., de Schauwer, E., Claus, L., de Munk, K., Van de Putte, I., \& Verstichele, M. (2013). Recognition and difference: A collective biography. International Journal of Studies in Education, 26(6), 680-691. Retrieved from http://dx.doi.org/10.1080/09518398.2013.788757

de Beauvoir, S. (2011). The second sex (C. Borde \& S. Malovany-Chevballier, Trans., Ed.). New York: Random House. (Original work published 1949)

Dewey, J. (1897). My pedagogic creed. School Journal, LIV (3), 77-80. Retrieved from http://playpen.meraka.csir.co.za/ acdc/education/Dr_Anvind_Gupa/Learners_Lib rary_7_March_2007/Resources/books/readings/17.pdf

Dewey, J. (1912). The child and the curriculum. Chicago, IL: Chicago University Press.

Dewey, J. (1915). Froebel's educational principles. In The school and society (pp. 111117). Chicago, IL: University of Chicago. Retrieved from http://www.brocku.ca/MeadProject/Dewey/Dewey_1907/Dewey_1915b.html

Dietz, M. G. (2003). Current controversies in feminist theorizing. Annual Review of Political Science, 6, 399-431. doi: 10.1146/annurev.polisci.6.121901.085635

Disch, S. (2012, September 6). The importance of dolls in early childhood. Retrieved from http://www.themagiconions.com/2012/09/discovering-waldorf-dolls-inearly-2.html

Dockterman, E. (2013, November 27). The war on pink: GoldieBlox toys ignite debate over what's good for girls. Time Magazine. Retrieved from http://healthland.time.com/2013/11/27/goldieblox-sparks-a-pink-toys-debate-thisholiday/\#ixzz2t3HBLzO1

Eidevald, C. (2009). Gendered violence produced during “freeplay” in preschool. International Journal of Equity and Innovation in Early Childhood, 7(2), 28-39.

Eisenberg, N., Murray, E., \& Hite, T. (1982). Children's reasoning regarding sex-typed toy choices. Child Development, 53(1), 81-86.

Ekelund, L., \& Bjurling, K. (Producers). (2004). Santa's workshop: Inside China's slave labour toy factories [Documentary film]. Sweden: Fair Trade Center \& Lotta Films for Swedwatch.

Ellis, A. C., \& Hall, G. S. (1896). A study of dolls. Pedagogical Seminary, 4(2), 129175. http://dx.doi.org/10.1080/08919402.1896.10534804 
International Journal of Child, Youth, and Family Studies (2014): 5(4.2) 782-807

Elton, S. (2013, March 15). Waldorf dolls: an anti-consumerist icon for \$700?

Whimsical and wholesome, Waldorf dolls provoke a Cabbage Patch-style frenzy.

Maclean's. Retrieved from http://www2.macleans.ca/2013/03/15/an-anticonsumerist-icon-for-700/

Formanek-Brunell, M. (1993). Made to play house: Dolls and the commercialization of American girlhood, 1830-1930. New Haven, CT: Yale University Press.

Fraser, A. (1966). A history of toys. London: Weidenfeld \& Nicolson.

Fung, Y. (2013, July 17). Guangdong villagers clash with factory workers over pollution. (L. Muddie, Trans.). Radio Free Asia. Retrieved from http://www.rfa.org/english/news/china/pollution-07162013162831.html

Gallacher, L. (2006). Block play, the sand pit and the doll corner: The (dis)ordering materialities of educating young children. Online papers archived by the Institute of Geography, School of Geosciences, University of Edinburgh. Retrieved from https://www.era.lib.ed.ac.uk/handle/1842/1002

Gane, N., \& Haraway, D. (2006). When we have never been human, what is to be done? Interview with Donna Haraway. Theory, Culture, Society, 23, 135-158. http://dx.doi.org/10.1177/0263276406069228

Gilligan, C. (1993). In a different voice. Boston: Harvard University Press. (Originally published 1982)

Golombok, S., Rust, J., Zervoulis, K., Croudace, T., Goulding, J., \& Hines, M. (2008). Developmental trajectories of sex-typed behavior in boys and girls: A longitudinal general population study of children aged 2.5 - 8 Years. Child Development, 79(5), 1583-1593. http://dx.doi.org/10.1111/j.1467-8624.2008.01207.x

Gong, J. (2013, July 10). China's Guangdong comes clean on soil pollution. Caixin Online. Retrieved from http://www.marketwatch.com/story/chinas-guangdongcomes-clean-on-soil-pollution-2013-07-15

Government of British Columbia. (2007). Toddler's first steps. Victoria, Canada: Crown Publications, Queen's Printer for British Columbia.

Government of British Columbia. (2009). Full day kindergarten program guide. Victoria, Canada: Crown Publications, Queen’s Printer for British Columbia.

Government of British Columbia. (n.d.a). Suggested StrongStart BC centre equipment list. Retrieved from http://www.bced.gov.bc.ca/early_learning/pdfs/equipment_list.pdf 
International Journal of Child, Youth, and Family Studies (2014): 5(4.2) 782-807

Government of British Columbia. (n.d.b). Suggested StrongStart BC outreach equipment list. Retrieved from http://www.bced.gov.bc.ca/early_learning/pdfs/equipment_list_outreach.pdf

Government of Manitoba. (n.d.). Materials/equipment list for preschool childcare centres. Retrieved from http://www.gov.mb.ca/fs/childcare/pubs/equipment_preschool_en.pdf

Grossman, E. (2009). Chasing molecules: Poisonous products, human health and the promise of green chemistry. Washington, DC: Island Press Shearwater Books.

Gruver, N. (n.d.). Stop segregating your toy aisle. Retrieved from http://www.change.org/petitions/target-stop-segregating-your-toy-aisles

Haraway, D. (1988). Situated knowledges: The science question in feminism and the privilege of partial perspective. Feminist Studies, 14(3), 575-599. http://dx.doi.org/10.2307/3178066

Haraway, D. (1991). A cyborg manifesto: Science, technology, and socialist-feminism in the late twentieth century. In D. Haraway, Simians, cyborgs and women: The reinvention of nature (pp.149-181). New York: Routledge.

Haraway, D. (1994). A game of cat's cradle: Science studies, feminist theory, cultural studies. Configurations, 2(1), 59-71.

Haraway, D. (1997).Modest_witness@second_millennium.Femaleman@_meets_ oncomouse $^{\mathrm{TM}}$. Feminism and technoscience. New York: Routledge.

Haraway, D. (2008). When species meet. Minneapolis, MN: University of Minnesota Press.

Haraway, D. (2010). When species meet: Staying with the trouble. Environment and Planning D: Society and Space, 28, 53-55. doi: 10.1068/d2706wsh

Haraway, D. (2012). Awash in urine: DES and Premarin ${ }^{\circledR}$ in multispecies responseability. Women's Studies Quarterly, 40(1 \& 2), 301-316. http://dx.doi.org/10.1353/wsq.2012.0005

Haraway, D., \& Goodeve, T. (2000). How like a leaf. New York: Routledge.

Hart, C., Pogrebin, L. C., Rodgers, M., \& Thomas, M. (2008). Free to be . . you and me. Philadelphia, PA: Running Press Kids. (Originally published 1972)

Hekman, S. (2010). The material of knowledge. Bloomington, IN: Indiana University Press.

Held, V. (2006). The ethics of care: Personal, political and global. New York: Oxford University Press. 
International Journal of Child, Youth, and Family Studies (2014): 5(4.2) 782-807

Hodgins, B. D. (2012). Pedagogical narrations’ potentiality as a methodology for child studies research. Canadian Children, 37(1), 4-11.

Hodgins, B. D. (2014). (Re)Storying dolls and cars: Gender and care with young children. Doctoral dissertation, University of Victoria, Victoria, Canada.

Retrieved from UVicSpace: http://hdl.handle.net/1828/5740

Hodgins, B. D., Kummen, K., Rose, S., \& Thompson, D. (2013, April 29). Pedagogical narrations as a methodology for educational research: Challenging multiple poverties. Paper presented at AERA Annual General Meeting, San Francisco, CA.

Hultman, K. (2009). A posthumanist deconstruction of gendered mathematical subjectivities. International Journal of Equity and Innovation in Early Childhood, 7(2), 16-27.

Jackson, A. Y. (2013). Posthumanist data analysis of mangling practices. International Journal of Qualitative Studies in Education, 26(6), 741-748. http://dx.doi.org/10.1080/09518398.2013.788762

Jackson, A. Y., \& Mazzei, L. A. (2012). Thinking with theory. New York: Routledge.

Jaffé, D. (2006). The history of toys. Phoenix Mill, UK: Sutton Publishing.

Johnson, S. (2011). Men in education: Reframing the gender issue. In T. Jacobson (Ed.), Perspectives on gender in early childhood (pp. 247-270). St.Paul, MN: Redleaf Press.

Journey to Crunchville. (2007, October 16). The much anticipated Waldorf doll. Retrieved from http://journeytocrunchville.wordpress.com/2007/10/16/the-muchanticipated-baby-doll/

Juelskær, M., \& Schwennesen, N. (2012). Intra-active entanglements - An interview with Karen Barad. Kvinder, Køn \& Forskning, 1-2, 10-23.

Knoblauch, J. A. (2009, July 2). Plastic not-so-fantastic: How the versatile material harms the environment and human health. Scientific American. Retrieved from http://www.scientificamerican.com/article.cfm?id=plastic-not-so-fantastic

Kovacs, B. (n.d.). Plastic. Retrieved from http://www.medicinenet.com/plastic/article.htm\#made

Kuhn, D., Nash, S. C., \& Brucken, L. (1978). Sex role concepts of two- and three-yearolds. Child Development, 49(2), 445-451. http://dx.doi.org/10.2307/1128709

Lather, P. (2013). Methodology-21: What do we do in the afterward? International Journal of Qualitative Studies in Education, 26(6), 634-645. http://dx.doi.org/10.1080/09518398.2013.788753 
International Journal of Child, Youth, and Family Studies (2014): 5(4.2) 782-807

Lather, P., \& St. Pierre, E. A. (2013). Post-qualitative research. International Journal of Qualitative Studies in Education, 26(6), 629-633. http://dx.doi.org/10.1080/09518398.2013.788752

MacLure, M. (2010). The offence of theory. Journal of Education Policy, 25(2), 277286. doi: 10.1080/02680930903462316

MacLure, M. (2013). Researching without representation? Language and materiality in post-qualitative methodology. International Journal of Qualitative Studies in Education, 26(6), 658-667. http://dx.doi.org/10.1080/09518398.2013.788755

MacNaughton, G. (2000). Rethinking gender in early childhood education. London: Paul Chapman Publishing.

McGeary, K. (2013, August 29). Guangdong getting more polluted by the day. The Nanfang. Retrieved from http://www.thenanfang.com/blog/pollution-round-upsz-river-and- guangdong-coal-mine-raise-concern/

Mama OT. (2012, November 25). Why kids should play with baby dolls (Yes even boys!). Retrieved from http://mamaot.com/2012/11/25/why-kids-should-play-with-babydolls-yes-even-boys/

Martin, C. L., Eisenbud, L., \& Rose, H. (1995). Children's gender-based reasoning about toys. Child Development, 66(5), 1453-1471. http://dx.doi.org/10.1111/j.1467-8624.1995.tb00945.x

Miller, C. L. (1987). Qualitative difference among gender stereotyped toys: Implications for cognitive and social development for girls and boys. Sex Roles, 16(9/10), 473487. http://dx.doi.org/10.1007/bf00292482

Mitchell, H. (1942). Play and play materials for the pre-school child (3rd ed.). Ottawa, Canada: The Canadian Welfare Council. (Original work published 1934)

Mommy footprint. (2012, December 11). Plastic dolls for Christmas. Retrieved from http://mommyfootprint.com/plastic-dolls-for-christmas/

Morris, S. (2012, March 14). Plastic baby dolls - Danger, danger, danger? Retrieved from http://saramorris.wordpress.com/2012/03/14/plastic-baby-dolls-dangerdanger-danger/

Moss, P., \& Petrie, P. (2002). From children's services to children's spaces: Public policy, children and childhood. New York: RoutledgeFalmer. http://dx.doi.org/10.4324/9780203995105

Noddings, N. (2003). Caring: A feminine approach to ethics and moral education (2nd ed.). Berkeley, CA: University of California Press. (Originally published 1984) 
International Journal of Child, Youth, and Family Studies (2014): 5(4.2) 782-807

Noddings, N. (2005). Caring in education. Retrieved from http://infed.org/mobi/caringin-education/

Pacini-Ketchabaw, V. (2005). Continuing rethinking the history of Ontario day nurseries: Loci for intervention, regulation, and administration. Child and Youth Care Forum, 35(2), 183-204. doi: 10.1007/s105666-005-9007-2

Prochner, L. (2011). “Their wooden little bricks”: A history of the material culture in kindergarten in the United States. Paedagogica Historica, 47(3), 355-375. http://dx.doi.org/10.1080/00309230.2010.513688

Pop, V. (2011, March 10). China tops Europe in plastics production. EU Observer. Retrieved from http://euobserver.com/china/113806

Puig de la Bellacasa, M. (2009). Touching technologies, touching visions. The reclaiming of sensorial experience and the politics of speculative thinking. Subjectivity, 28(1), 297-315. http://dx.doi.org/10.1057/sub.2009.17

Puig de la Bellacasa, M. (2010). Ethical doings in naturecultures. Ethics, Place \& Environment: A Journal of Philosophy \& Geography, 13(2), 151-169. http://dx.doi.org/10.1080/13668791003778834

Puig de la Bellacasa, M. (2012). "Nothing comes without its world”: Thinking with care. The Sociological Review, 60(2), 197-216. doi: 10.1111/j.1467954X.2012.02070.x

Rosevelt, M. (2006, December 3). What's toxic in toyland? Time Magazine Online. Retrieved from http://content.time.com/time/magazine/article/0,9171,1565564,00.html

Rubin, K. H. (1975). Day care and early childhood education in Ontario: A Canadian perspective. Child Care Quarterly, 4(3), 150-155. http://dx.doi.org/10.1007/bf01559360

Ruddick, S. (2002). Maternal thinking: Toward a politics of peace. Boston: Beacon Press. (Originally published 1980)

Sarnoff, R. L. (2003, October 11). Why I killed baby Ava. Retrieved from http://parentables.howstuffworks.com/health-wellness/i-killed-baby-ava.html

Schmidt, S. (2011, January 18). Canada's federal government to ban toxic chemical additive to plastic children's products. Retrieved from http://www.canada.com/health/Canada+federal+government+toxic+chemical+add itive+plastic+children+products/4122766/story.html

Smart baby, smart kid. (2013, May 21). Seven reasons wood toys are wayyyy better than plastic toys. Retrieved from http://smartbabysmartkid.com/7-reasons-wood-toysare-wayyyy-better-than-plastic-toys/ 
International Journal of Child, Youth, and Family Studies (2014): 5(4.2) 782-807

Sommers, C. H. (2012, December 6). You can give a boy a doll but you can't make him play with it: The logistical and ethical problems with trying to make toys genderneutral. Retrieved from http://www.theatlantic.com/sexes/archive/2012/12/youcan-give-a-boy-a-doll-but-you-cant-make-him-play-with-it/265977/

St. Pierre, E. A. (2011). Post qualitative research: The critique and the coming after. In N. K. Denzin \& Y. S. Lincoln (Eds.), The Sage handbook of qualitative research (4th ed., pp. 611-625). Thousand Oaks, CA: Sage.

St. Pierre, E. A. (2013): The posts continue: Becoming. International Journal of Qualitative Studies in Education, (26)6, 646-657. http://dx.doi.org/10.1080/09518398.2013.788754

Stoecklin, V. L. (2008). Making mindful choices for both children and mother earth. Retrieved from http://www.earlychildhoodnews.com/earlychildhood/article_view.aspx?ArticleID $\underline{=723}$

Strong-Boag, V. (1982) Intruders in the nursery: Childcare professionals reshape the years one to five, 1920-1940. In J. Parr (Ed.), Childhood and family in Canadian history (pp. 160-178). Toronto: McClelland \& Stewart.

Sutton-Smith, G. (1997). The ambiguity of play. Cambridge, MA: Harvard University Press.

Sweet, E. (2012). Guys and dolls no more? New York Times. Retrieved from http://www.nytimes.com/2012/12/23/opinion/sunday/gender-based-toymarketing-returns.html? $\mathrm{r}=0$

T. Eaton Co. Limited. (1897). Eaton’s Christmas catalogue. Retrieved from http://archive.org/stream/canadasgreatests00toro\#page/18/mode/2up

T. Eaton Co. Limited. (1909). Eaton's catalogue. Fall and winter 1909-1910. Retrieved from http://archive.org/stream/eatons190900eatouoft\#page/n0/mode/2up

T. Eaton Co. Limited. (1920). Eaton's catalogue. Fall and winter 1920-1921. Retrieved from http://archive.org/stream/eatons19202100eatouoft\#page/n417/mode/2up

T. Eaton Co. Limited. (1934). Eaton's catalogue. Fall and winter 1934-1935. Retrieved from http://www.collectionscanada.gc.ca/mailorder/029006-119.01e.php?\&page_ecopy=nlc003954.258\&\&PHPSESSID=icvguqkpstpoahkgh1vb2f2 $\mathrm{pb} 0$

Taylor, A. (2013). Reconfiguring the natures of childhood. New York: Routledge. 
International Journal of Child, Youth, and Family Studies (2014): 5(4.2) 782-807

Taylor, A., \& Blaise, M. (2014). Queer worlding childhood. Discourse: Studies in the Cultural Politics of Education, 35(3), 377-392. doi:

10.1080/01596306.2014.888842

Taylor, A., Blaise, M., \& Guigni, M. (2012). Haraway’s ‘bag lady story-telling’: Relocating childhood and learning within a 'post-human landscape'. Discourse: Studies in the Cultural Politics of Education, 34(1), 48-62. doi:10.1080/01596306.2012.698863

Taylor, A., \& Guigni, M. (2012). Common worlds: Reconceptualising inclusion in early childhood communities. Contemporary Issues in Early Childhood, 13(2), 108119. http://dx.doi.org/10.2304/ciec.2012.13.2.108

Taylor, A., \& Richardson, C. (2005). Queering home corner. Contemporary Issues in Early Childhood, 6(2), 163-174. http://dx.doi.org/10.2304/ciec.2005.6.2.6

Taylor, C. A., \& Ivinson, G. (2013). Material feminisms: New directions for education. Gender and Education, 25(6), 665-670. doi: 10.1080/09540253.2013.834617

Taylor, M. G. (1996). The development of children’s beliefs about social and biological aspects of gender differences. Child Development, 67(4), 1555-1571. http://dx.doi.org/10.1111/j.1467-8624.1996.tb01814.x

The Bump. (n.d.). 25 things to do with baby. Retrieved from http://pregnant.thebump.com/new-mom-new-dad/baby-basics/articles/things-todo-with-baby.aspx?MsdVisit=1

Theimer, C. E., Killen, M., \& Stangor, C. (2001). Young children’s evaluations of exclusion in gender-stereotypic peer contexts. Developmental Psychology, 37(1), 18-27. http://dx.doi.org/10.1037//0012-1649.37.1.18

Thottam, J. (2007, September 6). This Christmas, a lump of lead? Time Magazine Online. Retrieved from http://content.time.com/time/magazine/article/0,9171,1659711,00.html

Thrift, N. (2003). Closer to the machine? Intelligent environments, new forms of possession and the rise of the supertoy. Cultural Geographies, 10(4), 389-407. doi: 10.1191/1474474003eu282oa

Toloken, S. (2012, January 12). China toy factories face troubles. Plastic News. Retrieved from http://www.plasticsnews.com/article/20120112/NEWS/301129961/china-toyfactories-face-troubles\#

Toys R Us Canada. (n.d.). Girls’ toys. Retrieved from http://www.toysrus.ca/category/index.jsp?categoryId=4192038 
International Journal of Child, Youth, and Family Studies (2014): 5(4.2) 782-807

Tronto, J. C. (1993). Moral boundaries: A political argument for an ethic of care. New York: Routledge.

Van der Tuin, I. (2008). Deflationary logic: Response to Sara Ahmed’s “Imaginary prohibitions. Some preliminary remarks on the founding gestures of the "new materialism”'. European Journal of Women's Studies, 15(1), 411-416. doi: $10.1177 / 1350506808095297$

Van Patten,D. (n.d.). Can you buy a baby doll that is not made in China? Exploring where the majority of dolls are made today. Retrieved from: http://collectdolls.about.com/od/babydolls/a/madeinchina.htm

Varga, D. (1997) Constructing the child: A history of Canadian day care. Toronto: James Lorimer.

Wagner-Ott, A. (2002). Analysis of gender identity through doll and action figure politics in art education. Studies in Art Education, 43(3), 246-263. http://dx.doi.org/10.2307/1321088

Winestock, S. L. (2010). Security theory and the history of developmental psychology. In R. Volpe (Ed.), The secure child: Timeless lessons in parenting and childhood education (pp. 69-96). Charlotte, NC: Information Age Publishing.

White, L. B. (2009). Dangerous plastics, safe plastics. Mother Earth News. Retrieved from http://www.motherearthnews.com/natural-health/dangerous-plastics-safeplastics-zmaz09aszraw.aspx\#axzz2eWMhhMsM

Zapf Creation. (2009). Parents guide. Retrieved from http://www.zapfcreation.com/en/parent-s-guide/

Zolotow, C. (2002). William’s doll. In Harper Collins Treasury of picture book classics (pp. 257-286). New York: Harper Collins. (Originally published 1972) 
International Journal of Child, Youth, and Family Studies (2014): 5(4.2) 782-807

\section{Endnotes}

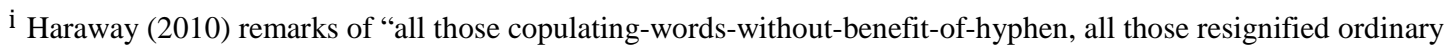
words: Are they really necessary?” (p. 53). The hyphen has been used to join words together to indicate their relationship in an effort to avoid privileging one over the other. Barad (2007) does so with material-discursive, which is akin to Haraway's (1994) material-semiotic, "emphasiz[ing] the absolute simultaneity of materiality and semiosis" (Haraway \& Goodeve, 2000, p. 137). Removing the hyphen takes the visual representation of this relatedness further, marking the words (phenomena) as not simply connected but inseparable. For example Barad's (2007, 2011) term spacetimemattering, and Haraway’s (2008, 2010) naturecultures and materialsemiotic (Haraway, 2010). Haraway tells her reader: "what I'm interested most of all are 'naturecultures' - as one word - implosions of the discursive realms of nature and culture” (p. 105). In this spirit, one of the ways in which I play with language in this article is with term past-presents(presence). Connecting the words in this way is an effort to highlight that pasts and presents, as in time, as well as presence, as in being "there", are intra-active in their iterative becoming (see Barad, 2007). Jackson and Mazzei (2012) discuss this conceptualization of inseparability (drawing on Barad, 2007) in terms of how it shifts thinking about data analysis. They write:

The implication for how we think data differently, given this entangled state, is to move away from thinking the interview and what is told discursively, toward a thinking of the interview and what is "told" as discursive, as material, as discursive and material, as material $\leftrightarrow$ discursive, and as constituted between the discursive and the material in a posthumanist becoming. (Jackson \& Mazzei, 2012, p. 126)

ii St. Pierre (2013) has expressed caution about the notion of the "material turn”, a quick sweep of condemning researchers and theorists from the 1970s and 1980s as "too discursive" without acknowledging the attention paid to the material by many of the "post" thinkers of the "discursive turn" (see also Hekman, 2010). Ahmed (2008) criticized what she perceived as a lack of careful reading of early feminist writings by new materialism writers. Van der Tuin's (2008) response to Ahmed includes:

I call this new materialism a third-wave materialism. I have chosen to do so, not because I want to set up another (feminist) progress narrative, but rather to signify the non-dualistically organized epistemic realm to which Rosi Braidotti has alluded. This is the feminist epistemic realm where we do not find the constitution of a (historical) materialism "proper" or the uncritical celebration of feminist standpoint theory, nor do we find feminist biologies of the past. What we find here is feminist generation. (p. 415)

While I applaud Ahmed's call for careful reading, and her pointedly observed comments about which writers get particular, deep, “thinking-with", I think her critique is overly simplified, albeit important. Barad (whom Ahmed takes to task in her critique, pointing perhaps un-carefully to pieces of her earlier writing) is also cautious of the take up of the term "new" (see Juelskær \& Schwennesen, 2012). Like van de Tuin (2008), Barad is interested in the generation of new knowledges, not as a "breaking with the past, but rather a dis/continuity, a cutting together-apart with a very rich history of feminist engagements with materialism” (Juelskær \& Schwennesen, 2012, p. 13). It is with this perspective that I engage with theoretical insights and troublings both recent and previous from within feminism, science studies, and early childhood education. As MacLure (2010) suggests “definition is problematic, if not downright disreputable, as far as postfoundational theories are concerned. This is because definition, as a practice, assumes a secure distinction between words and the things or concepts to which they refer. ... Definitions falter, meaning shifts. The impossibility of defining theories, and knowing the precise difference between one and another, is not therefore a fatal error but an unavoidable issue” (p. 279).

iii Barad's (2007) term intra-action “signifies the mutual constitution of entangled agencies” (p. 33, italics original). Barad makes clear that, "in contrast to the usual 'interaction', which assumes that there are separate individual agencies that precede their interaction, the notion of intra-action recognizes that distinct agencies do not precede, but rather emerge through, their intra-action” (p. 33). This is mattering as always-becoming, co-constitutive emergence, mentioned in the article's introduction.

iv Haraway (1997) writes of gender, "with all its tangled knots with other systems of stratified relationships” (p. 27). Her work attends to the entanglement of gender, race, sexuality, politics, and economics, among many other "categories". "Gender is the relation between variously constituted categories of men and women (and variously arrayed tropes), differentiated by nation, generation, class, lineage, color, and much else” (Haraway, 1997, p. 28). Elsewhere I attend to this entanglement in greater detail than there is space for within this article. Other thinking-with dolls analyses address the entanglement of gender, care, racialization, class, and sexuality, in relation to past-present practices and discourses of production and curriculum (Hodgins, 2014). 
International Journal of Child, Youth, and Family Studies (2014): 5(4.2) 782-807

v Barad (2007) explains diffraction as relating to the way waves (any kind of waves: sound, light, water) combine and spread out when they encounter interference: "When waves meet, they don't disrupt or obstruct each other, no impact or collision occurs, as in the case of two particles. On the contrary, the whole point is that the waves can coexist unhindered by each other's presence; they can overlap in a common spatial region - indeed at a single point” (p. 417). Another important point that Barad (2007) makes is that a quantum understanding of diffraction recognizes that, in certain circumstances, matter manifests wave behaviour and, conversely, light manifests particle behaviour. This is referred to as the "wave-particle duality paradox" (p. 83) and suggests the "complexity and profundity of diffraction phenomena” (p. 83).

vi As mentioned (Endnote i), Haraway is purposeful in her use of a hyphen or a slash for resignifying words. Her recent (Haraway, 2012) use of response-ability emphasizes the "response" element, an actual doing, within the notion of responsibility. She write of "a praxis of care and response - response-ability” (p. 302).

vii According to Library and Archives Canada (2007)[NOTE: Not on Reference List], the T. Eaton Company was the first Canadian retailer to distribute a catalogue in Canada (the first one distributed in 1884 and the last in 1976), and was an important vehicle for merchandising across the vast and sparsely settled country.

viii For an overview see Formanek-Brunell (1993). For a few recent critiques about the "pink aisle” see Crozier (2014), Dockterman (2013), and Gruver (n.d.). For critiques and comments about the gendering of dolls, see Sweet (2012). 